\title{
Water quality assessments and metagenomic analysis of the polluted river Apatlaco, Mexico
}

Luz Breton-Deval*1, Katy Juárez¹, Alejandro Sánchez-Flores ${ }^{1}$, Rosario VeraEstrella ${ }^{1}$

1-Instituto de Biotecnología, Universidad Nacional Autónoma de México, Avenida Universidad 2001, Colonia Chamilpa, Cuernavaca, Morelos 62210, México

\section{*Corresponding author:}

Dr. Luz Breton-Deval

E-mail: Izbreton@ibt.unam.mx

Instituto de Biotecnología, Universidad

Nacional Autónoma de México, Avenida

Universidad 2001, Colonia Chamilpa,

Cuernavaca, Morelos 62210, México.

\section{Keywords}

metagenomics, water pollution, river, superficial water, whole metagenome shotgun 


\title{
Water quality assessments and metagenomic analysis of the polluted
}

\author{
river Apatlaco, Mexico
}

4 ABSTRACT

The aim of this study is to analyze the water quality parameters and bacterial

6 diversity and thereby understand the effect of water quality on the microbial population structure in the river. The following parameters: total coliforms,

8 chemical oxygen demand, harness, ammonium, nitrite, nitrate, total Kjeldahl nitrogen, dissolved oxygen, total phosphorus, total dissolved solids, and temperature were analyzing along 17 sampling points in the river. The worst levels of pollution were $510 \mathrm{mg} / \mathrm{L}$ chemical oxygen demand, $7 \mathrm{mg} / \mathrm{L}$ nitrite, 45 $\mathrm{mg} / \mathrm{L}$ nitrate, $2 \mathrm{mg} / \mathrm{L}$ dissolved oxygen, and $756 \mathrm{mg} / \mathrm{L}$ of total dissolved solids. Whole metagenome shotgun sequencing was performed at 4 key points along the river (P1,P7,P10 and $\mathrm{P} 17)$, the first point had clean water and the other points were polluted, as a result of this pollution, the structure of microbial communities along the river have changed. Proteobacteria and Bacteroidetes were the most representative phyla with a relative abundance of 57 and $43 \%$ respectively for P1, 82 and $15 \%$ for $P 7,69$ and $27 \%$ for $P 10$ and 87 and $10 \%$ for the last point $\mathrm{P} 17 . \mathrm{P} 1$ is rich in microorganism such as Limnohabitans a planktonic bacterium very common in freshwater ecosystems. However, in P7, P10 and P17 are rich in opportunistic pathogens such as Acinetobacter Arcobacter and Myroides that endangers the health of around 1.6 million people which live around the area. These results elucidate the influence of the pollution on the microbial community and the likely effects on the health of the people around. 


\section{Introduction}

Microbial communities in river systems are diverse and dynamic in composition, sometimes as a consequence of environmental changes, diverse stresses and varying nutrient profiles [1]. Microbial communities participate in carbon nitrogen and other biogeochemical cycles in water as well as driving primary production through photosynthetic activity [2]. Furthermore, the maintenance and biodegradation activities are linked to microbial diversity of superficial waters [3]. In this case study, the discharge of wastewater from industrial and urban activities, perhaps has been impacted the structure and function of microbial communities and has consequently disrupted the nutrient cycles and negatively affected energy flow to higher trophic levels [4,5]. Furthermore, contaminants can represent a dangerous source of pathogens for the people who live within the river basin [6]. Rodríguez-Tapia et al [7] developed an ecological model which correlates epidemiological studies with the pollution present in The Atoyac River located in Puebla, Mexico, finding a causal relationship between water contamination and gastrointestinal diseases. This highlights how important it is for communities to have access to clean water for hydration, food production and sanitation. If proper sanitation services are not available, rates of disease are further increased by polluted water [8].

44 The metabolic potential of superficial water microorganisms is crucial for the transformation and degradation of the pollutants present, including heavy metals, pesticides, and organic waste. Therefore, understanding the diversity and structure of microbial communities can help to indicate the level of pollution in the system and allow us to anticipate the rehabilitation of aquatic ecosystems [9]. 
The current study was conducted in The Apatlaco River, a waterway located in

Morelos, Mexico. This river receives 321 official wastewater discharges, 158 are from the industrial sector and 137 and 26 are from the domestic and agricultural sectors, respectively. Therefore, the pollutants present in The Apatlaco River are very diverse in type and high in volume (CONAGUA-SEMARNAT, 2016). At the origin of the river $(\mathrm{P} 1)$ the water is clean, and the river doesn't receive any discharge. Later parts of the river receive numerous different kinds of discharges and consequently the water quality is similar to wastewater. As a result, P1 provides a clean water source to which we have been able to compare measurements from other parts of the river.

Scientific knowledge about the diversity, function, and metabolic pathways of microorganisms in polluted environments is necessary. The Microorganisms present in waterways and the identification of chemical reactions linked to metabolism present in polluted environments can significantly contribute to providing scientific evidence of the effect of pollutants on microbiome diversity and their role as a selective pressure.

In the past, studies of ecology and diversity of microbes were approached with classical techniques. However, most of the microorganism in the environment are unculturable [10]. Currently, advances in DNA sequencing technology such as whole metagenome shotgun (WMS) exhibits a rich profile of microbial communities due to all DNA is cut into tiny fragments and sequenced, resolution 70 is broader than the universal $16 \mathrm{~S}$ marker gene profiles, which only analyze the $16 S$ locus [11]. The aim of this study is to analyze water quality parameters and bacterial diversity and thereby understand the effect of water quality on the microbial population structure in the river. 


\section{2. Materials and Methods}

\subsection{Study site and sample collection}

76 The Apatlaco River passes through the small state of Morelos in central Mexico (Figure 1). The Apatlaco River is $63 \mathrm{~km}$ long and runs through 10 municipalities

in Morelos. Due to its short length and its water's heterogeneous characteristics, the river provides a convenient model for the evaluation of anthropogenic effects on microbiota. In Morelos there are two primary seasons: the rainy season and the dry season. The rainy season lasts from June to September and during the rest of the year the climate is approximately $24 \pm 2{ }^{\circ} \mathrm{C}$. The dry season is the best time to conduct field research given that the microorganisms present during the rainy season are not representative of stable river conditions. Water samples were collected at 17 sampling points along The Apatlaco River (table 1).

Sampling field trips were conducted every two months during 2018 in order to span the entire cycle of hydrological variation. Methanogenic analyses used samples from four key points of the river: P1, P7, P10 and P17. At each point (P1, P7, P10, P17), 10 different water samples were collected and then combined 90 to form a single sample for molecular analyses.

\subsection{Environmental parameters measured in the Apatlaco River}

Physical and chemical parameters of the river were measured on site using a HANNA multi parametric instrument DR900. This device measures key

parameters such as $\mathrm{pH}$, dissolved oxygen (OD), turbidity, ammonium (NH), nitrite $\left(\mathrm{NO}_{2}-\mathrm{N}\right)$ nitrate $\left(\mathrm{NO}_{3}-\mathrm{N}\right)$. Total nitrogen $(\mathrm{TN})$, total phosphorus (TP) and chemical

oxygen demand (COD) were determined with the colorimetric method using $\mathrm{HACH}$ digester DRB200. Temperature was measured by a thermometer, Total 
98 coliforms and total dissolved solids (TDS) were measured according to Standard Methods [12]

\subsection{DNA extraction and Sequencing}

DNA was extracted from water samples using a DNeasy PowerWater Kit

102 (QIAGEN, Hilden, Germany). For each sample, an Illumina library was prepared from total DNA using the TruSeq kit v2 (Illumina, Inc., San Diego, CA, USA) 104 following the manufacturer's specifications with an average fragment size of 500 bp. The sequencing was performed on the NextSeq500 (Illumina, Inc., San

106 Diego, CA, USA) platform with a 150-cycle configuration, generating paired-end reads with a length of $75 \mathrm{bp}$.

\subsection{Data Analysis}

After performing a quality control analysis using the FASTQC program [13], the

110 taxonomic profiling was performed using the raw reads with the software MetaPhlan v2.0 [14] using the following parameters: --bt2_ps sensitive-local -min_alignment_len 95 --input_type fastq.

In addition to the MetaPhlan analysis, the software MEGAN6 was used to

114 evaluate the taxonomic distribution of each read based on the comparison of BLASTX with all the sequences in the NCBI-NR databank.

\subsection{Statistical analysis}

Statgraphics Centurion Software (Statpoint Technologies, Inc., Warrenton,

118 Virginia, USA) was used for the principal component analysis (PCA) and to measure the water quality differences between the polluted and unpolluted sites (ANOVA). 


\section{3. Results and Discussion}

\subsection{Water quality in The Apatlaco River}

124 At the first sample point (P1) the physicochemical analysis showed values of water quality suitable for irrigation, fishing, and recreation. The water quality of

126 the river at this location is good and the aquatic ecosystem is healthy (Table 2, Figure 2) $[15,16]$. However, wastewater effluents start to enter the river and contaminate the water from the second sample point (P2) onwards. This contamination can be observed via the increased presence of fecal coliforms, collections of microorganisms that live in the intestines of humans and animals, at higher rates than the legally permitted limits. At P2, the river has levels of 200

132 coliform colonies $/ 100 \mathrm{ml}$ and therefore this water cannot be used for recreational activities, nor fishing or irrigation. The most significant presence is at P7, where 31400 coliform colonies/100 ml are present. Another important parameter widely used to examine organic pollutants in water systems is chemical oxygen demand (COD). The highest values of COD were located at P5 with $320 \mathrm{mg} / \mathrm{L}$ and P12 with $360 \mathrm{mg} / \mathrm{L}$ as a result of 137 domestic discharge points. Typical wastewater has a COD around $400 \mathrm{mg} / \mathrm{l}$ [17]. The rate of COD also affects the values of DO; high values of COD cause low levels of DO. DO values follow the same trend found for COD; the worst levels of DO were found between P5 and P12 at around $3 \mathrm{mg} / \mathrm{L}$. Low levels of DO can cause anoxic zones in the river and this stimulates 142 microorganisms such as sulfate-reducing bacteria that release noxious gases such as hydrogen sulfide, or methanogenic bacteria that release methane gases; one of the most potent greenhouse gases [18].

The total dissolved solids (TDS) and the degree of hardness both increase over the course of the river due to the accumulation of ions and other compounds such 
as calcium, chloride, sodium, nitrates, phosphates and metals derived from the dumping of industrial wastewater [19].

The concentration of different species of nitrogen is correlated with season and river flow. However, there are some rivers in which one of these factors, flow or season, is more influential than the other. For example, the total nitrogen and 152 nitrate collected in The Stillwater River and The Great Miami River (both in Fairfield, Ohio, USA) tends to increase as the current intensifies. In contrast, the same parameters in The Mad River in Dayton, Ohio, tend to remain constant for the entire length of the river and throughout the year [20]. Regarding the different species of nitrogen in The Apatlaco River, the $\mathrm{NO}_{2}-\mathrm{N}$ values start to increase from P3 onwards, with values of $4 \mathrm{mg} / \mathrm{L}$. It is well known that levels up to $1 \mathrm{mg} / \mathrm{L}$ of $\mathrm{NO}_{2}-\mathrm{N}$ can react with proteins and form carcinogenic $\mathrm{N}$-nitrosamines [21]. The same trend can be observed for $\mathrm{NO}_{3}-\mathrm{N}$, where abnormal values appear at $\mathrm{P} 3$, with $45 \mathrm{mg} / \mathrm{L}$. The source of $\mathrm{NO}_{3}-\mathrm{N}$ could be organic or inorganic and possibly come from waste discharge, animal waste or artificial fertilizers. Both anions $\left(\mathrm{NO}_{2}\right.$ and $\mathrm{NO}_{3}$ ) were found in lesser quantities from P13 onwards, however the factor that most affects the concentration of nitrogen species along this river is not the different flow rates but the multiple discharges of wastewater along the length of this body water. This effect is more evident with the values of $\mathrm{NH}_{3}-\mathrm{N}$ and TKN that showed fluctuations possibly associated with discharges of wastewater [22]. The concentration of total phosphorus starts at $0.77 \mathrm{mg} / \mathrm{L}$ and varies along the river, the highest point $(24 \mathrm{mg} / \mathrm{L})$ is reached at sampling point 5 . 
$172 \quad 3.2$ Taxonomic assignment of metagenomic data along four sites in The Apatlaco River

174 Taking in account variations of physicochemical parameters along the waterway were selected four sites along the river in order to perform the metagenomic analysis. Figure 3 provides a map of bacteria diversity in the different sampling points as can be seen the diversity in every point is different. The principal phyla in terms of relative abundance at P1 were Proteobacteria and Bacteroidetes with $57 \%$ and $43 \%$, respectively. $51 \%$ of the Proteobacteria phyla corresponded to Betaproteobacteria class and Burkholderiales accounted $50 \%$ of total at order level, $47 \%$ of which were Comamonadacea, $44 \%$ were classified as Limnohabitans genus. Limnohabitans is a common member of bacterioplankton in freshwater habitats which plays an important role in carbon transfer to higher trophic levels [23-25]. Another important freshwater planktonic bacterium is Polynucleobacter which is usually found in the same habitats as Limnohabitans

[26]. At P7 the level of Limnohabitans decreased to $15 \%$ which is strong evidence of the severe impact of wastewater contamination of the freshwater ecosystem.

188 At P10, where there is a discharge of the local PTAR, the relative abundance of Limnohabitans declines further to $5 \%$. It is possible that the bacteria from the PTAR discharge compete with Limnohabitans and thereby displace them.

P7 is severely impacted by wastewater discharges from both industrial and 192 domestic source. At this site, Proteobacteria was the most representative Phulym with $82 \%$ abundance and Bacteroidetes decreased to $15 \%$. At Class level the abundance was: Gammaproteobateria 53\%, Betaproteobacteria 25\%, Epsilonproteobacteria 3\%, Flavobacteria 12\% and Sphingobacteria 3\%. The 
Gammaproteobacteria, which included the Moraxellaceae family $50 \%$ and

Pseudomonadaceae family $2 \%$. Acinetobacter is represented with $49 \%$ and it is important to mention that because this genera are free living saprophytes widely used in biotechnological applications including bioremediation of several compounds such as phenol, hexadecane, diesel etc. but also some species as

202 A. baumanii is a water organism recently identified as an opportunistic pathogen in humans, affecting people with compromised immune systems, and is becoming increasingly important as a hospital-derived (nosocomial) infection $[27,28]$. The other family identified was Pseudomonadaceae. The principal genera of Pseudomonadaceae was Pseudomonas 1.7\%, a microorganism with the ability to adapt and colonize several ecological environments including water, sewage, soil, plants, animals, and humans [29]. Their powerful metabolism facilitates their frequent use in bioremediation projects as it is well known that they can degrade phenols, hydrocarbons, pesticides, heavy metals and dyes [30-32]. At P1 the relative abundance of Pseudomonas was less than

$2121(0.7 \%)$ however from $\mathrm{P} 7$ onwards their relative abundance begins to increase, and at $\mathrm{P} 17$ their relative abundance was $7 \%$. The other $15 \%$ of the bacteria

214 found at P7 were phylum Bacteroidetes where 5\% are from the Sphingobacteriaceae family and $10 \%$ from the Flavobacteriaceae family.

216 Compared with $\mathrm{P} 1$, the relative abundance of the all genera were diminished.

P10 is located following a PTAR treated-water discharge and has the highest 218 levels along the river for parameters such as $\mathrm{COD}, \mathrm{NH}_{3}-\mathrm{N}$ and $\mathrm{NO}_{2}-\mathrm{N}$. (Table 2). In this context, microbial relative abundance changes to $69 \%$ for Proteobacteria and $27 \%$ for Bacteroidetes. The most abundant class of Proteobacteria phylum was Epsilonprotobacteria with $45 \%$ of relative abundance, all of which comes 
222 from genus Arcobacter. Of the 15 species of this genera, $A$ butzleri, $A$. cryaerophilus and $A$. skirrowii are considered emerging pathogens in

224 gastrointestinal infections and extra intestinal invasive diseases [33]. The remaining $25 \%$ of relative abundance is dispersed between

226 Gammaproteobacteria 15\% and Betaproteobacteria 9\%. Most of the Gammaproteobacteria were Pseudomonadales 11\%, Moraxellaceae family with 228 the genera Acinetobacter 6\% and Pseudomonadaceae family with the genera Pseudomonas 5\%. Almost all Betaproteobacteria were Burkholderiales 8\%.

230 While the $27 \%$ of the phylum Bacteroidetes were distributed in class Flavobacteriia 15\%, family Flavobacteriaceae, mainly in the following genera, 232 Myroides 6\%, Riemerella 4\%, Cellulophaga 2\%, Gillisia 1\% and $12 \%$ in the class Bacteroidia, order Bacteroidales, families Prevotellaceae 7\%, Bacteroidaceae 4\% and Porphyromonadaceae $1 \%$.

The final sampling point, $\mathrm{P} 17$, present the same trend as $\mathrm{P} 7$, an enrichment of

236 Proteobacteria 87\% and a decrease in Bacteroidetes 10\%. Most of the Proteobacteria were Betaproteobacteria class $66 \%$ of which $62 \%$ were from 238 Burkholderiales order, $44 \%$ from the Comamonadaceae family and $12 \%$ from the Burkholderiaceae family. The other class were Gammaproteobacteria 13\%, which Pseudomonadaceae genus was $8 \%$, Flavobacteriia $7 \%$ were Flavobacteriaceae 6\%, Epsilonproteobacteria 6\% were Campylobacteraceae , 242 Alphaproteobacteria $2 \%$ and Actinobacteria 1\% as can be seen in Figure 4. 


\subsection{Relationships between water quality factors and bacterial community}

The corresponding ANOVA indicates that polluted sites (P7, P10 y P17) have

significant differences $(p=0.0094)$ in parameter levels compared with the unpolluted site, P1, with a significance of $95 \%$.

250 The PCA showed that the first three principal components explain $87 \%$ of the data variance (Table 3). The first PCA explains $46 \%$ of the variance and is strongly related (>0.35) with $\mathrm{NO}_{2}, \mathrm{COD}$ and $\mathrm{DO}$ (Figure 5). These water quality parameters describe organic contamination as a result of domestic discharges where high levels of organic matter consume dissolved oxygen present in the river and perhaps due to high amounts of COD, in some parts of the river, there are a simultaneous methanogenesis and nitrogen removal via $\mathrm{NO}_{2}$ [34]. As a result, in the $\mathrm{P} 10$, the site with highest levels in $\mathrm{COD}$ and $\mathrm{NO}_{2}$ and the lowest levels in DO the dominant microorganisms who have been able to live with low levels of $\mathrm{O}_{2}$ were Arcobacter genus which requires around $10 \%$ of $\mathrm{O}_{2}$ for survive and the genera Prevotella which is anaerobic. There are other interesting genus present in every point however some arrived in the discharges and are not a microorganism which live there for the chemical conditions of the water such as Acinetobacter genus. This genus has their highest abundance in P7 and in P10 their abundance decreases due to the chemical conditions and the competition with other bacteria. The second PCA explains $30 \%$ of the variance and were strongly related $(>0.35)$ with hardness, TDS and temperature. These water quality parameters provide information about the concentration of dissolved or suspended compounds such as carbonate, chlorides, sulfates, phosphates, nitrates, magnesium, calcium, sodium and metals [35] (fig. 2). The increase in hardness and TDS could block light and thus reduce the rate of photosynthesis, 
causing a reduction in the levels of dissolved oxygen and altering the trophic chains [36]. The highest levels of TDS, hardness and temperature were at P17. The principal genera founded there were Limnohabitans, a planktonic bacterium founded in abundance in $\mathrm{P} 1$, is likely the microorganism of this genera tolerates better high levels of TDS and hardness than organic pollution. Other genera that 276 increase their abundance levels in that point were Thiomonas which has the ability to oxidize arsenite and thiosulfate and used as energy source $[37,38]$. As well as, Pseudomonas which at that point their abundance showed the highest level. The final PCA explains $12 \%$ of the variance and is related to TP and $\mathrm{NH}_{3}$,

280 the higher levels of both compounds were between P1 and P7 and after the P10 their levels were constants along the points for that reason is not possible differentiate their impact in the microbial structure.

\section{Conclusion}

This study evidence that The River Apatlaco has been damage with different kinds of discharges along their riverbed, $\mathrm{P} 10$ has the highest levels in $\mathrm{COD}, \mathrm{NH}_{3}$, $\mathrm{NO}_{2}, \mathrm{NO}_{3}$, TP and the lowest level in dissolved oxygen while at the end of the river TDS and harness showed their highest levels. The principal component analysis showed that first component explains $46 \%$ of the variance in the system and is strongly related with $\mathrm{NO}_{2}, \mathrm{COD}$ and $\mathrm{DO}$, key parameters for develop a healthy aquatic life. As a result of this pollution, the structure of microbial communities along the river have changed. P1 is rich in Limnohabitans a planktonic bacterium very common in freshwater ecosystems. However, in P7,

P10 and P17 there are microorganism such as Acinetobacter Arcobacter and Myroides, which usually are not there and are a danger for human health, now 
are an important part of the microbial community and this endangers the health of around 1.6 million of people who live in the area around. There are other microorganisms such as Pseudomonas, Thiomonas and Acinetobacter which have change their abundance due to the changes in the chemical water conditions. These microorganisms have the metabolic machinery to be used in future bioremediation projects if there are stimulate property

\section{Acknowledgements}

304 The authors thank UNAM-IBT, Mexico for financial support to this research. Also, LB-D thank to Consejo Nacional de Ciencia y Tecnología (CONACYT) and their program CATEDRAS for support the Project 285

\section{Reference}

1. Nogales B, Aguiló-Ferretjans MM, Martín-Cardona C, Lalucat J, Bosch R.

\section{2. Hou D, Huang Z, Zeng S, Liu J, Wei D, Deng X, et al. Environmental factors} shape water microbial community structure and function in shrimp cultural

314 enclosure ecosystems. Frontiers in Microbiology. 2017;8:1-12.

316 Bacterial diversity along a $2600 \mathrm{~km}$ river continuum. Environmental Microbiology. 2015;17:4994-5007.

318 4. Elnaker NA, Elektorowicz M, Naddeo V, Hasan SW, Yousef AF. Assessment of Microbial Community Structure and Function in Serially Passaged

320 Wastewater Electro-Bioreactor Sludge: An Approach to Enhance Sludge Settleability. Scientific Reports [Internet]. Springer US; 2018;8:1-11. Available from: http://dx.doi.org/10.1038/s41598-018-25509-2

5. Liu J, Chen X, Shu H yue, Lin X rui, Zhou Q xing, Bramryd T, et al. Microbial community structure and function in sediments from e-waste contaminated rivers at Guiyu area of China. Environmental Pollution [Internet]. Elsevier Ltd;

326 2018;235:171-9. Available from: https://doi.org/10.1016/j.envpol.2017.12.008

6. Lipp EK, Farrah SA, Rose JB. Assessment and impact of microbial fecal pollution and human enteric pathogens in a coastal community. Marine Pollution Bulletin. 2001;42:286-93. gastrointestinal diseases. International Journal of Environmental Research and Public Health. 2017;14. 
8. Gui D, He J, Zhang X, Tu Q, Chen L, Feng K, et al. Potential association between exposure to legacy persistent organic pollutants and parasitic body burdens in Indo-Pacific finless porpoises from the Pearl River Estuary, China.

336 Science of the Total Environment [Internet]. Elsevier B.V.; 2018;643:785-92. Available from: https://doi.org/10.1016/j.scitotenv.2018.06.249

338 9. Liang Z, Siegert M, Fang W, Sun Y, Jiang F, Lu H, et al. Blackening and Odorization of Urban Rivers: A bio-geochemical process. FEMS Microbiology

340 Ecology [Internet]. 2017;1-12. Available from: http://academic.oup.com/femsec/advance-

342 article/doi/10.1093/femsec/fix180/4780270

10. Techtmann SM, Hazen C. Metagenomic applications in environmental monitoring and bioremediation. Journal of Industrial Microbiology \& Biotechnology. Springer Berlin Heidelberg; 2016;

346 11. Sharpton TJ. An introduction to the analysis of shotgun metagenomic data. 2014;5:1-14.

348 12. APHA. Standard Methods for the Examination of Water and Wastewater. 20th ed. Federation APHAAWWAWE, editor. Washington, DC, USA; 1998.

350 13. Andrews. FastQC: a quality control tool for high throughput sequence data [Internet]. 2010. Available from:

352 http://www.bioinformatics.babraham.ac.uk/projects/fastqc

14. Duy Tin Truong, Adrian Tett, Edoardo Pasolli, Curtis Huttenhower NS.

354 Microbial strain-level population structure and genetic diversity from metagenomes. Genome Research. 2017;27:626-38.

356 15. García-rodríguez J, Molina-astudillo FI, Castelán HQ. Distribución y sistemática del fitoplancton a lo largo del río Amacuzac (Morelos , México). $358 \quad 2011 ; 21: 11-23$.

16. La EN, Del C, Apatlaco RÍO. ANÁLISIS ENTRE ESCURRIMIENTOS y SEDIMENTOS HISTÓRICOS EN LA CUENCA DEL RÍO APATLACO, MOR. ANALYSIS OF RUNOFF AND HISTORICAL SEDIMENTS IN THE APATLACO

362 RIVER bASIN, MOR. Preciado, J. M 1 , Arganis, J. M. L. 2,3 , Val, S. R. 3 y G. A. Ocón. Analysis. 2010;2:39-44.

364 17. van den Brand TPH, Roest K, Chen G-H, Brdjanovic D, van Loosdrecht MCM. Effects of Chemical Oxygen Demand, Nutrients and Salinity on Sulfate-

366 Reducing Bacteria. Environmental Engineering Science [Internet]. 2015;32:858-64. Available from:

368 http://online.liebertpub.com/doi/10.1089/ees.2014.0307

18. Whitehead P, Bussi G, Abed M, Dolk M, Das P, Comber S, et al. Science of 370 the Total Environment Restoring water quality in the polluted Turag-Tongi-Balu river system , Dhaka: Modelling nutrient and total coliform intervention

372 strategies. Science of the Total Environment [Internet]. Elsevier B.V.; 2018;631632:223-32. Available from: https://doi.org/10.1016/j.scitotenv.2018.03.038

374 19. Waziri M, Ogugbuaja VO. Interrelationships between physicochemical water pollution indicators : A case study of River Yobe-Nigeria. American Jouran of

Scientific and Industrial Research. 2010;1:76-80. 
20. Mcd. Nitrogen and Phosphorus Concentrations and Loads in the Great Miami River Watershed. The Miami Conservation District. 2011;43:3-27.

21. Kilfoy BA, Zhang Y, Park Y, Holford TR, Schatzkin A. NIH Public Access. 2012;129:160-72.

22. Duan R, Fedler CB. Preliminary field study of soil TKN in a wastewater land application system. Ecological Engineering [Internet]. Elsevier B.V.; 2015;83:14. Available from: http://dx.doi.org/10.1016/j.ecoleng.2015.05.051

384 23. Grujčić V, Kasalický V, Šimek K. Prey-specific growth responses of freshwater flagellate communities induced by morphologically distinct bacteria from the genus Limnohabitans. Applied and Environmental Microbiology. 2015;81:4993-5002.

388 24. Shabarova T, Kasalický V, Šimek K, Nedoma J, Znachor P, Posch T, et al. Distribution and ecological preferences of the freshwater lineage LimA (genus Limnohabitans) revealed by a new double hybridization approach. Environmental Microbiology. 2017;19:1296-309.

392 25. Jezberová J, Jezbera J, Znachor P, Nedoma J, Kasalický V, Šimek K. The Limnohabitans genus harbors generalistic and opportunistic subtypes: Evidence 394 from spatiotemporal succession in a canyon-shaped reservoir. Applied and Environmental Microbiology. 2017;83:1-15.

396 26. Horňák K, Kasalický V, Šimek K, Grossart HP. Strain-specific consumption and transformation of alga-derived dissolved organic matter by members of the Limnohabitans- $C$ and Polynucleobacter-B clusters of Betaproteobacteria. Environmental Microbiology. 2017;19:4519-35.

400 27. Paisio CE, Talano MA, González PS, Magallanes-Noguera C, Kurina-Sanz $\mathrm{M}$, Agostini E. Biotechnological tools to improve bioremediation of phenol by

402 Acinetobacter sp. RTE1.4. Environmental Technology (United Kingdom) [Internet]. Taylor \& Francis; 2016;37:2379-90. Available from: http://dx.doi.org/10.1080/09593330.2016.1150352

28. Howard A, Donoghue MO, Feeney A, Sleator RD. Acinetobacter baumannii An emerging opportunistic pathogen. 2012;243-50.

29. Kittinger C, Lipp M, Baumert R, Folli B, Koraimann G, Toplitsch D, et al.

408 Antibiotic resistance patterns of Pseudomonas spp. isolated from the river Danube. Frontiers in Microbiology. 2016;7:1-8.

410 30. Roy U, Sengupta S, Banerjee P, Das P, Bhowal A, Datta S. Assessment on the decolourization of textile dye (Reactive Yellow) using Pseudomonas sp.

412 immobilized on fly ash: Response surface methodology optimization and toxicity evaluation. Journal of Environmental Management [Internet]. Elsevier;

414 2018;223:185-95. Available from: https://doi.org/10.1016/j.jenvman.2018.06.026

416 31. Wasi S, Tabrez S, Ahmad M. Use of Pseudomonas spp. for the bioremediation of environmental pollutants: A review. Environmental Monitoring and Assessment. 2013;185:8147-55.

32. Ramadass K, Megharaj M, Venkateswarlu K, Naidu R. Bioavailability of 
420 weathered hydrocarbons in engine oil-contaminated soil: Impact of bioaugmentation mediated by Pseudomonas spp. on bioremediation. Science of

422 the Total Environment [Internet]. Elsevier B.V.; 2018;636:968-74. Available from: https://doi.org/10.1016/j.scitotenv.2018.04.379

424 33. Kayman T, Abay S, Hizlisoy H, Ibrahim Atabay H, Serdar Diker K, Aydin F. Emerging pathogen Arcobacter spp. in acute gastroenteritis: Molecular

426 identification, antibiotic susceptibilities and genotyping of the isolated arcobacters. Journal of Medical Microbiology. 2012;61:1439-44.

428 34. Zhaoming Zheng, Yun Li , Jun Li , Yanzhuo Zhang, Wei Bian, Jia Wei BZ and JY. Effects of carbon sources, COD / NO À $2-\mathrm{N}$ ratios and temperature on

430 the nitrogen removal performance of the simultaneous partial nitrifi cation, anammox and denitrifi cation ( SNAD ) biofilm. Water Science and Technology.

432 2017;1712-21.

35. Shirokova VL, Ferris FG. Microbial Diversity and Biogeochemistry of a

434 Shallow Pristine Canadian Shield Groundwater System. Geomicrobiology Journal. 2013;30:140-9.

436 36. Bechtel A, Schubert CJ. Biogeochemistry of particulate organic matter from lakes of different trophic levels in Switzerland. Organic Geochemistry [Internet].

438 Elsevier Ltd; 2009;40:441-54. Available from: http://dx.doi.org/10.1016/j.orggeochem.2009.01.011

440 37. Hovasse A, Bruneel O, Casiot C, Desoeuvre A, Farasin J, Hery M, et al. Spatio-Temporal Detection of the Thiomonas Population and the Thiomonas

442 Arsenite Oxidase Involved in Natural Arsenite Attenuation Processes in the Carnoulès Acid Mine Drainage. Frontiers in Cell and Developmental Biology

444 [Internet]. 2016;4:1-14. Available from:

http://journal.frontiersin.org/article/10.3389/fcell.2016.00003

446 38. Prieto-Barajas CM, Alfaro-Cuevas R, Valencia-Cantero E, Santoyo G. Efecto de la estacionalidad y de los parámetros fisicoquímicos sobre las 448 comunidades bacterianas de tapetes microbianos de manantiales termales de Araró, México. Revista Mexicana de Biodiversidad [Internet]. Universidad

450 Nacional Autónoma de México, Instituto de Biología; 2017;88:616-24. Available from: http://dx.doi.org/10.1016/j.rmb.2017.07.010 
454 Table 1 Sampling points in the Apatlaco River

\begin{tabular}{ccccc}
\hline Point & Points name & Latitude & Longitude & Altitude (MSNM) \\
\hline P1 & Apatlaco Abajo Chalchihuapan & -99.26872 & 18.97372 & 1866 \\
P2 & Apatlaco Antes Descarga Municipal Tétela & -99.257992 & 18.96491 & 1797 \\
P3 & Apatlaco Antes Cárcamo De San Antón & -99.2446 & 18.92331 & 1520 \\
P4 & Apatlaco Arriba Ptar Chipitlan & -99.22684 & 18.87091 & 1318 \\
P5 & Apatlaco Antes Arroyo Chapultepec & -99.22312 & 18.86305 & 1275 \\
P6 & Apatlaco Aguas Abajo 2 Derivadora & -99.22209 & 18.85309 & 1438 \\
P7 & Puente Temixco & -99.2187 & 18.83 & 1232 \\
P8 & Arriba Ptar El Rayo & -99.22056 & 18.82885 & 1154 \\
P9 & Apatlaco Antes Arroyo Panocheras & -99.22397 & 18.80168 & 1145 \\
P10 & Apatlaco Después De La Cascada Real Del Puente & -99.23337 & 18.78971 & 1128 \\
P11 & Apatlaco Xochitepec & -99.23472 & 18.77434 & 1056 \\
P12 & Apatlaco Después Arroyo Palo Escrito & -99.2339 & 18.76212 & 1072 \\
P13 & Apatlaco Después Arroyo Tetlama & -99.24011 & 18.70103 & 994 \\
P14 & Apatlaco Antes Descarga Tetelpa & -99.19877 & 18.66185 & 922 \\
P15 & Arroyo Poza Honda Arriba Rio Apatlaco & -99.196561 & 18.655017 & 918 \\
P16 & Apatlaco Antes 9-Derivadora & -99.18538 & 18.62544 & 900 \\
P17 & Rio Apatlaco Tlatenchi & -99.18278 & 18.60914 & 891 \\
\hline
\end{tabular}


456 Table 2 The measurements of chemical parameters along the river

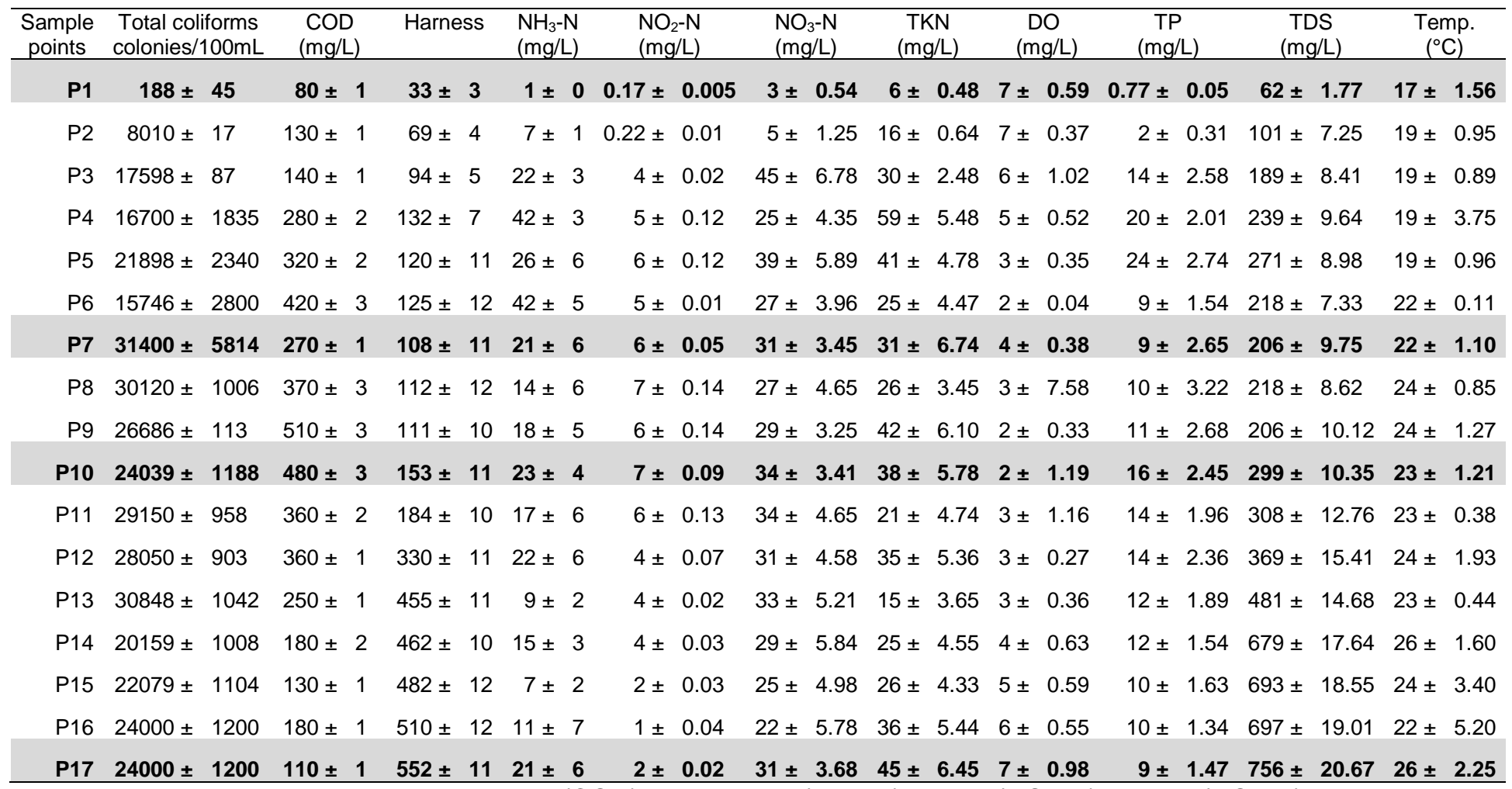

Note: chemical oxygen demand (COD), ammonium (NH3-N), nitrite (NO2-N), nitrate (NO3-N),

458 total Kjeldahl nitrogen (TKN), dissolved oxygen (DO), total phosphorus (TP), total dissolved solids

(TDS) 
460 Table 3 Principal component analysis and their weight of the chemical parameters analyzed in the river

\begin{tabular}{rrrrrrr}
\hline parameters & PC1 & $(\%)$ & \multicolumn{1}{c}{ PC2 } & \multicolumn{1}{c}{$(\%)$} & \multicolumn{1}{c}{ PC3 } & \multicolumn{1}{c}{$(\%)$} \\
\hline COD & 0.38613 & 14.90948 & -0.18010 & 3.24346 & -0.32881 & 10.81180 \\
DO & -0.40753 & 16.60831 & 0.07549 & 0.56986 & 0.31694 & 10.04491 \\
Hardness & -0.02517 & 0.06335 & 0.56230 & 31.61768 & 0.10342 & 1.06949 \\
$\mathrm{NH}_{3}$ & 0.27547 & 7.58837 & -0.18004 & 3.24151 & 0.44629 & 19.91721 \\
$\mathrm{NO}_{3}$ & 0.37177 & 13.82144 & 0.12579 & 1.58221 & 0.33589 & 11.28194 \\
$\mathrm{NO}_{2}$ & 0.43337 & 18.78130 & -0.14377 & 2.06710 & -0.09176 & 0.84205 \\
TCOL & 0.35053 & 12.28678 & 0.26986 & 7.28239 & -0.18528 & 3.43268 \\
TDS & 0.00173 & 0.00030 & 0.55760 & 31.09222 & 0.16103 & 2.59307 \\
TEMP & 0.19851 & 3.94062 & 0.43926 & 19.29520 & -0.34455 & 11.87126 \\
TP & 0.34641 & 12.00013 & -0.00911 & 0.00830 & 0.53043 & 28.13560 \\
Eigenvalue & 4.57900 & & 2.97440 & & 1.15430 & \\
Variability (\%) & 45.79100 & & 29.74400 & & 11.54300 & \\
Cumulative & 45.79100 & 100.00 & 75.53500 & 100.00 & 87.07900 & 100.00 \\
\hline
\end{tabular}

462

464

466

468

470

472

474

476

478

480 
482

484
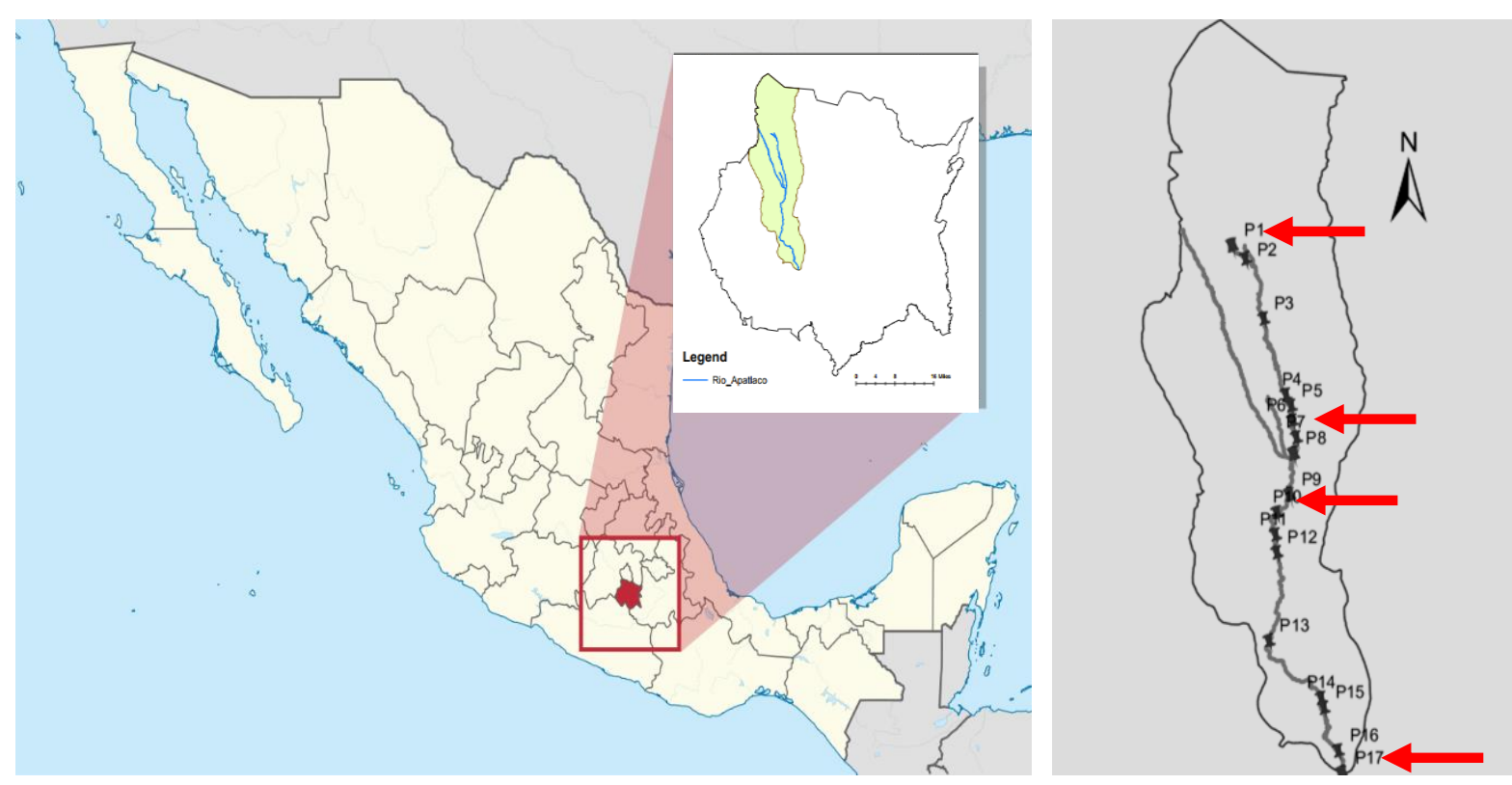

492

Figure 1. The Apatlaco River basin with the names of sampling points along the 494 river. The red arrows indicate the sampling points (P1, P7, P10 and P17) used for the metagenomic analysis 


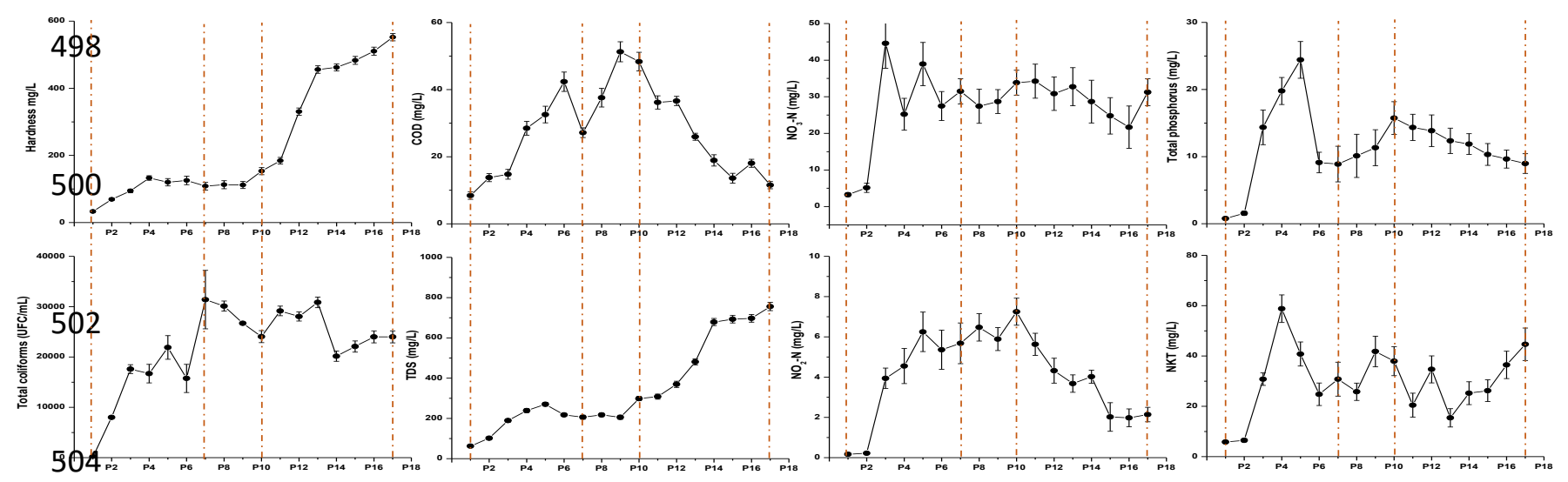

Figure 2. The most representative chemical parameters along the river. The red

506 dotted lines indicate the sampling points (P1, P7, P10 and P17) used for the metagenomic analysis 


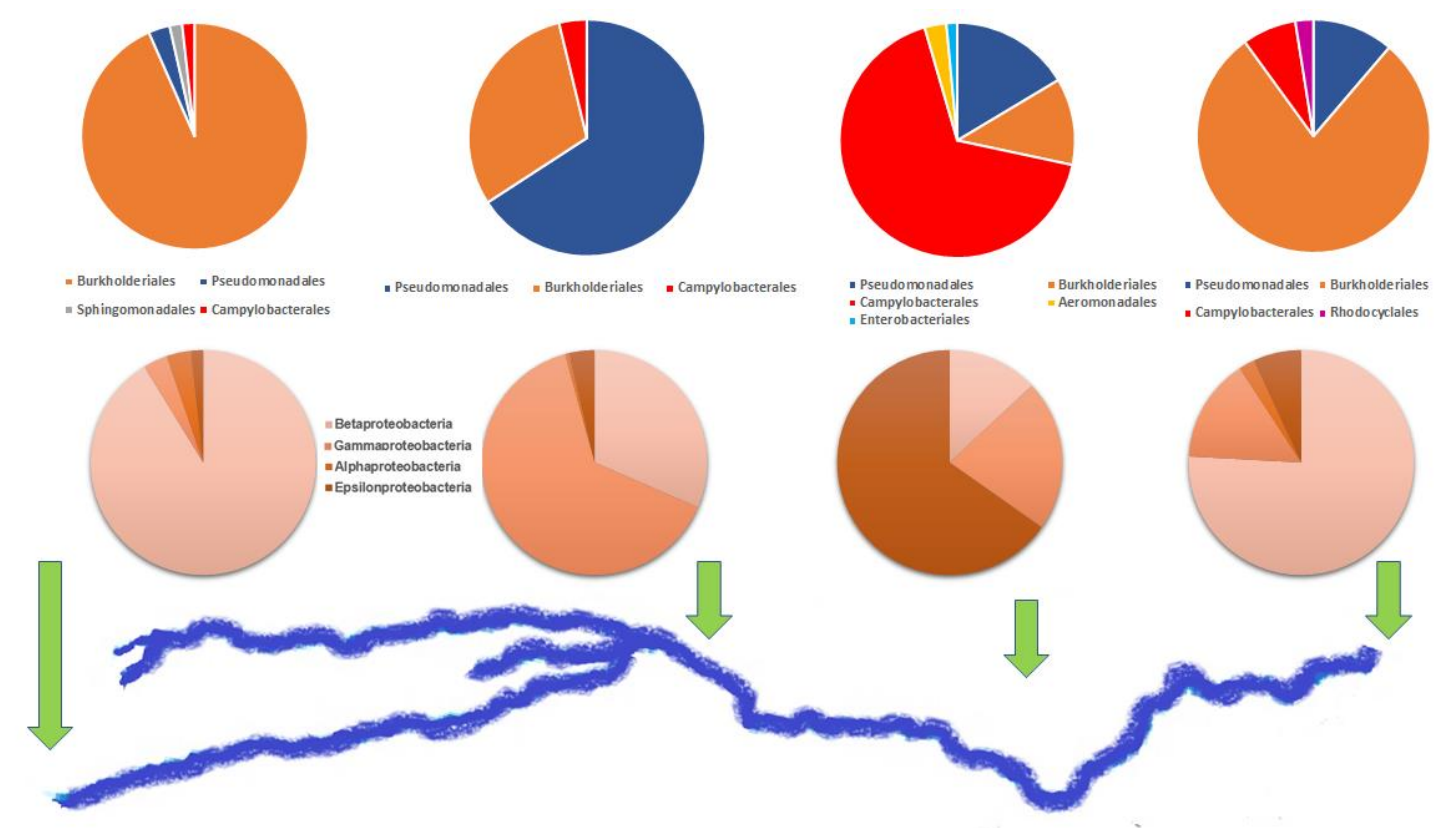

Figure 3. Associations between kind of proteobacteria (down circles) and genera 512 (top circles) with the geographical location in the 4 most relevant points (P1, P7, P10, P17) 
bioRxiv preprint doi: https://doi org/10 1101/536128. this version posted January 31 2019. The copyriaht holder for this preprint (which was not certified by peer review) is the author/funder, who has granted bioRxiv a license to display the preprint in perpetuity. It is made available under aCC-BY-ND 4.0 International license.

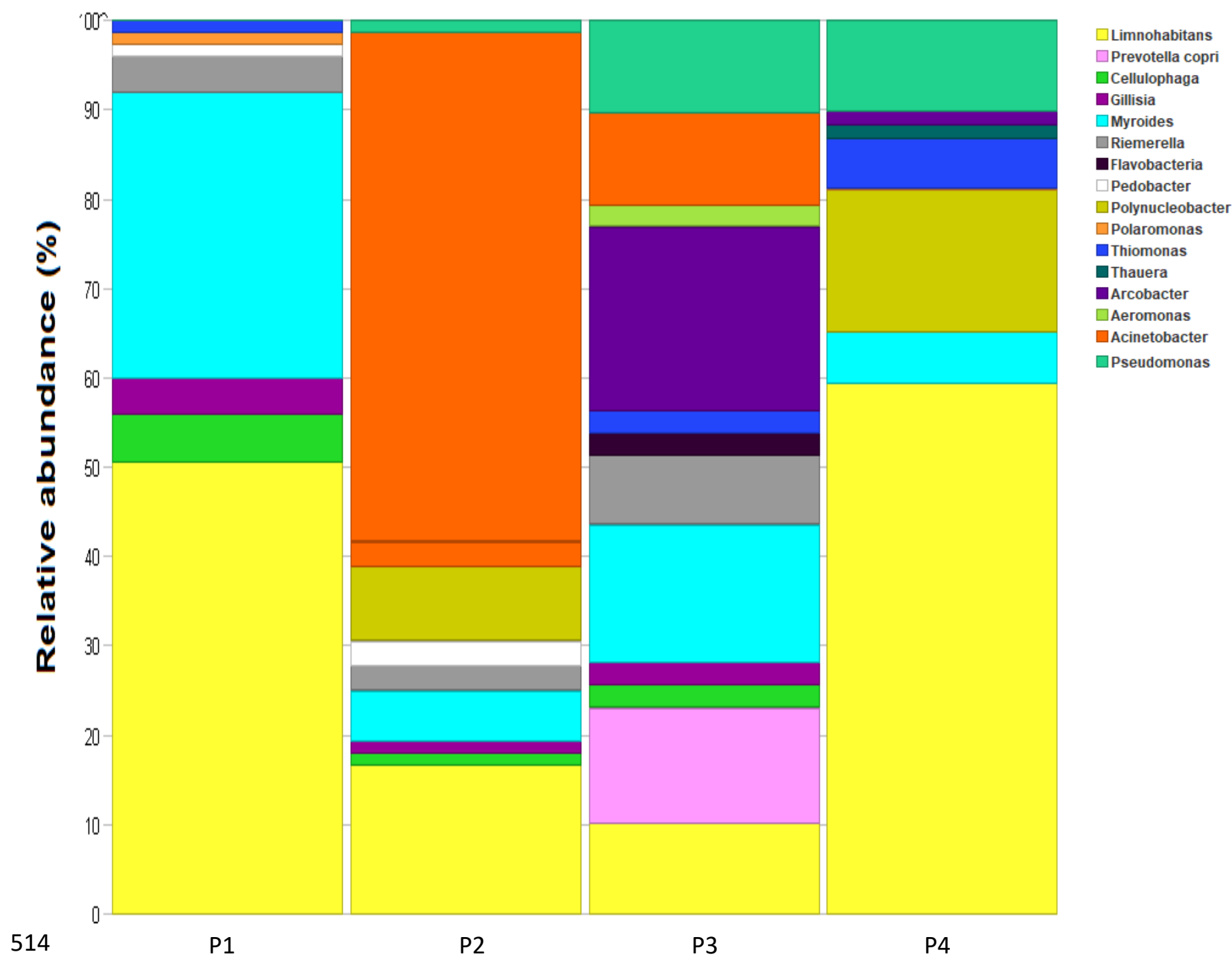

Figure 4. Phylogenetic profile along the river. Where $\mathrm{P} 1$ is clean water and $\mathrm{P} 7$, $516 \quad \mathrm{P} 10$ and P17 polluted water. 


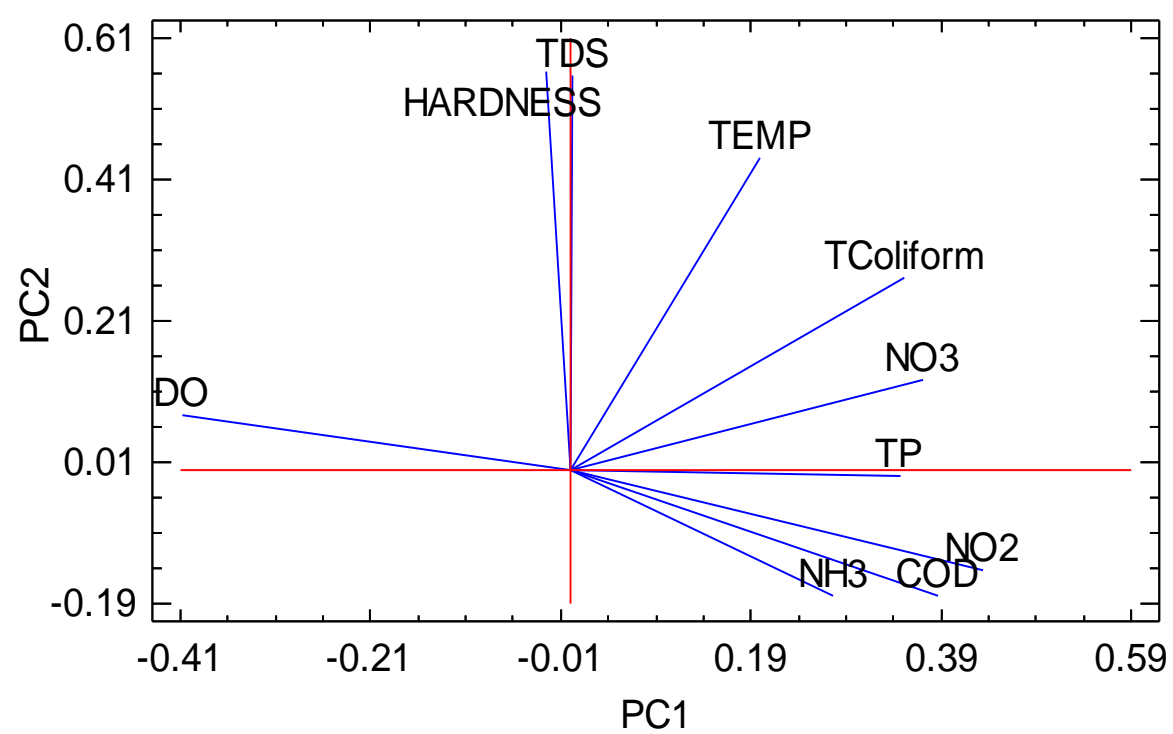

528 Figure 5. Principal component analysis plot of the chemical parameters 